\title{
PELATIHAN PENALARAN MATEMATIKA JENIS SOAL UJIAN NASIONAL BERBASIS KOMPUTER (UNBK) JENJANG SMP UNTUK MENINGKATKAN KUALITAS PENGAJAR DAN MINAT SISWA PADA BIMBINGAN BELAJAR DAN PRIVAT MATRIKS
}

\author{
Aden ${ }^{1)}$, Choirul Basir ${ }^{2)}$, Nunung Kusdaniyama ${ }^{3)}$ \\ 1,2,3Program Studi Matematika, Fakultas Matematika dan Ilmu Pengetahuan Alam, Universitas Pmulang
}

\begin{abstract}
Abstrak
Penalaran matematika merupakan modal dasar dalam memahami persoalan penyelesaian matematika. Sehingga perlu mempunyai metode yang tepat dalam penyelesaian soal matematika khususnya soal UNBK baik bagi tingkatan SD maupun SMP. Tujuan dari pengabdian kepada masyarakat yaitu mengetahu terjadinya penigkatan kemampuan penalaran penyelesaian persoalan matematika pad tutor Bimbel dan Privat Matrik serta mengetahui dorongan apakah yang diperlukan untuk meningkatkan penalaran matematika. Metode yang digunakan yaitu metode Uji t dua sampel. Hasil pengabdian menyatakan bahwa terjadi peningkatan penalaran kemampuan dalam menyelesaikan persoalan matematika. Hal yang perlu ditingkatkan yaitu perlu menambah kuantitas latihan soal-soal yang bervariatif
\end{abstract}

Kata Kunci: Uji T, penalaran.

\begin{abstract}
Mathematical reasoning is the basic asset in understanding mathematical problem solving. So it is necessary to have the right method in solving math problems, especially UNBK questions for both SD and SMP levels. The purpose of community service is to find out the increase in the ability to solve mathematical problem solving in Bimbel and Private Matrix tutors and to find out what encouragement is needed to improve mathematical reasoning. The method used is the two-sample t test method. The results of the service stated that there was an increase in reasoning ability in solving mathematical problems. The thing that needs to be improved is that it is necessary to increase the quantity of practice questions which are varied
\end{abstract}

Keywords: T test, reasoning 


\section{PENDAHULUAN}

\subsection{Latar Belakang}

Usaha bimbingan belajar masih menjadi bisnis yang menjanjikan seiring berkembangnya tingkat kompetensi siswa/i sekolahan meski diiringi juga tingginya kompetisi antar bimbingan belajar. Kategori konsumen bukan hanya terletak pada siswa/i sebagai objek pembelajaran namun juga terkadang orangtua juga memberikan penilaian berdasarkan tingkat layanan yang sudah terbrand di masyarakat luas. Meski terkadang realitanya berbeda dengan ketika promosi awal dari brand tersebut. Dan orang tua juga turut andil dalam menentukan bimbingan belajar tempat putra/i nya akan didaftarkan dengan harapan minimal adalah segala permasalah belajar putra/i nya dapat terbantu terlebih untuk siswa/i menjelang Ujian Nasional, sudah dipastikan target bukan hanya pada permasalah belajar sehari-hari namun juga target nilai bagus pada saat Ujian nasional dan mendapatkan sekolah negeri atau swasta favorite yang diharapkan.

Pada faktor inilah bimbingan belajar yang baru sering kalah brand dengan bimbingan belajar yang sudah eksis sebelumnya, terlebih bimbingan belajar tersebut didukung dengan finansial dan segala faktor penunjang yang sudah terstruktur dari lama. Meski bukan tidak mungkin bimbingan belajar dengan brand baru dapat mengalahkan bimbingan belajar dengan brand yang sudah eksis sebelumnya. Diperlukan banyak terobosan baru yang menyajikan layanan yang berbeda terlebih dapat memberikan sesuatu yang lebih bagus dari layanan bimbingan belajar yang sudah eksis sebelumnya.

Ketika bimbingan belajar hanya menawarkan metode pembelajaran yang sama persis dengan disekolahan maka konsumen biasanya lebih cenderung kurang dipilih meskipun harga dan layanan yang lain mempengaruhi juga. Tetapi sering juga ketika metode pengajaran lebih menyenangkan dan memberi solusi lebih cepat dan tepat, konsumen bersedia untuk membayar meski dengan harga tinggi sekalipun. Memang banyak faktor untuk membuat bimbingan belajar diminati konsumen, namun metode belajar biasanya masih mendominasi alasan konsumen mengikuti bimbingan belajar yang berimbas pada kualitas pengajar. Sehingga diperlukan pelatihan pengajar bimbingan belajar yang bertujuan untuk mengupgrade metode belajar pengajar dan menjadikan wadah bagi pengajar bidang studi untuk senantiasa mengevaluasi beberapa metode belajar dan penyampaian nya.

Semakin tingginya tingkat kompetisi bimbingan belajar mengharuskan adanya kreatifitas dalam layanan baik itu bersifat fisik maupun non fisik. Salah satu bentuk kreatifitas non fisik adalah membuat beberapa layanan pembeda dengan beberapa kompetitor bimbingan belajar terutama dalam penyelesaian soal dengan metode yang lebih menarik. Bimbingan Belajar dan Privat Matriks awal didirikan pertama pada bulan Juni 2017 dengan awal pembukaan cabang di Reni Jaya Pamulang Barat tepatnya di Jl. Surya Kencana Pamulang Barat Tangerang Selatan (Seberang Sekolah Muhammadiyah) meski di bulan Juli 2018 Bimbingan Belajar dan Privat Matriks Pamulang bergeser beberapa ruko dari ruko semula ke tempat yang sekarang karena tempat sebelumnya tidak dapat menampung jumlah siswa dan parkiran yang tidak seluas yang sekarang.

Selanjutnya di bulan September 2017 dilakukan pembukaan cabang ke-2 Bimbingan Belajar dan Privat Matriks Pamulang Permai yang bertempat di Jl. 
Pelatihan Penalaran Matematika Jenis Soal Ujian Nasional Berbasis Komputer (UNBK) Jenjang SMP Untuk Meningkatkan Kualitas Pengajar Dan Minat Siswa Pada Bimbingan Belajar dan Privat Matriks ...(Aden)

Pamulang Permai Blok A1 No.3 Pamulang Barat Tangerang Selatan (dekat saluran pipa gas) untuk mengakomodir permintaan beberapa konsumen di wilayah Pamulang Permai dan sekitar.

Pada bulan November 2017 dilakukan pembukaan cabang ke-3 Bimbingan Belajar dan Privat Matriks Kebon Jeruk bertempat di Jl. Lapangan Bola 5B Kebon Jeruk Jakarta Barat ( Dibelakang RCTI atau MNC Studio) dengan perolehan siswa fantastis di tahun pertama 210 siswa dan terus meningkat di tahun selanjutnya. Di Bulan Juli 2019 dilakukan pembukaan cabang ke-4 Bimbingan Belajar dan Privat Matriks Taman Palem bertempat di bekas bimbingan belajar yang tutup karena bangkrut yaitu di Ruko Pelangi Blok E No.5 Cengkareng Jakarta Barat dan ternyata lumayan antusiasme dari sekolah di daerah Cengkareng dan sekitar. Bimbingan Belajar dan Privat Matriks hadir karena begitu banyaknya bimbingan belajar dengan berbagai layanan yang ditawarkan terkadang memberikan harga yang sangat tinggi dan jarang mengakomodasi kalangan menengah ke bawah. Padahal layanan yang ditawarkan masih dalam kualitas standar pelayanan. Berikut ini merupakan profil lengkap dari mitra,

Nama : Bimbingan Belajar dan Privat MATRIKS

Mulai Berdiri : Juni 2017

\subsection{Rumusan Masalah}

Rumusan masalah pada pengabdian ini yaitu:

1). Apakah terjadi peningkatan penalaran kemampuan dalam menyelesaikan persoalan matematika UNBK untuk tutor setelah proses pelatihan?

2). Apakah yang harus didorong kepada tutor untuk meningkatkan kemampuan penalaran penyelesaian persoalan matematika UNBK?

\subsection{Tujuan Pengabdian Kepada Masyarakat}

Tujuan pengabdian kepada masyarakat yang dilaksanakan di Bimbingan dan Privat Matriks yaitu:

1). Meningkatan penalaran kemampuan dalam penyelesaian persoalan matematika UNBK untuk tutor setelah proses pelatihan?

2). Menentukan apa yang harus didorong kepada tutor untuk meningkatkan kemampuan penalaran penyelesaian persoalan matematika UNBK

\subsection{Manfaat Pengabdian kepada Masyarakat}

Manfaat dari kegiatan pengabdian kepada masyarakat ini adalah membantu Bimbingan dan Privat Matriks dalam mengatasi persoalan-persoalan yang dihadapi saat ini dalam meningkat penalaran penyelesaian persoalan soal UNBK khususnya mata pelajaran matematika. Secara khusus tujuan kegiatan pengabdian kepada masyarakat ini adalah:

1). Membantu untuk menumbuhkan kesadaran kepada tutor untuk berlatih secara terus menerus dalam menyelesaikan persoalan matematika.

2). Membantu Bimbel dan Privat Matriks dalam menambah alternatif penyelesaian persoalan matematika. 


\subsection{Tinjauan Pustaka}

\subsubsection{Matriks}

Matrik merupakan susunan bilangan yang teratur yang terdiri dari kolom dan baris dengan jumlah tertentu. Jenis-jenis matriks yaitu:

a. Matriks Baris

Matriks baris merupakan matriks yang hanya terdapat satu baris. Ordo matriks baris yaitu $\mathrm{n}$ 1. Misalkan:

$$
A=\left[\begin{array}{lll}
2 & 4 & 5
\end{array}\right]
$$

b. Matriks Kolom

Matriks kolom merupakan matriks yang hanya terdiri dari satu kolom.

Ordo matriks kolom yaitu $1 \mathrm{x} \mathrm{n}$.

c. Matrik Persegi

Matriks persegi merupakan matriks yang terdiri dari jumlah kolom dan baris sama jumlahnya. Ordo matrik persegi yaitu n x n

d. Matriks Balok

Matriks balok merupakan matriks yang jumlah kolom dan baris salah satunya terbesar atau berbeda. Ordonya yaitu $\mathrm{n} \times \mathrm{m}$. Untuk besarnya $\mathrm{n}$ lebkih besat dari $\mathrm{m}$ atau jumlah $\mathrm{n}$ lebih kecil dari $\mathrm{m}$.

e. Matriks Segitiga Atas

Matriks segitiga atas merupakan matriks yang berada di bawah garis diagonal nilainya nol. Dengan bentuk matriks dapat berbentuk persegi maupun balok.

f. Matriks Segitiga Bawah

Matriks segitiga bawah merupakan matrik yang berada di atas garis diagonal mol.empunyai nilai nol. Dengan bentuk matriknya berupa matriks persegi maupun matriks balok.

g. Matriks Identitas

Matriks identitas merupakan matriks yang berbentuk persegi serta nilai diagonalnya bernilai 1 serta yang lainnya nol.

\subsubsection{Metode Crammer}

Metode crammer merupakan metode penyelesaian terhadap sebuah persamaan linier dengan menggunakan matriks dengan prinsip penggunaan determinan dengan hsail yang unik.( Anton Howard: 2012) (Perumusan untuk menentukan nilai dari sebuah persamaan yaitu:

$$
\begin{aligned}
& x=\frac{\operatorname{Det}(X)}{\operatorname{Det}(A)} \\
& y=\frac{\operatorname{Det}(Y)}{\operatorname{Det}(A)}
\end{aligned}
$$

\subsubsection{Metode Penyelesaian Matematika dengan Menggunakan Penalaran}

Metode penyelesaian penalaran meruapakn penyelesaian persoalan matematika dengan menggunakan pemahaman dasar yang lebih dikembangkan. Sehinga metode ini lebih mengedapankan pemahamn dasar 
Pelatihan Penalaran Matematika Jenis Soal Ujian Nasional Berbasis Komputer (UNBK) Jenjang SMP Untuk Meningkatkan Kualitas Pengajar Dan Minat Siswa Pada Bimbingan Belajar dan Privat Matriks ...(Aden)

yang dikembangkan dengan membuang bebrapa langkah sehingga penyelesaian lebih cepat dan akurat dalam menyelesaikan persoalan matematika. Selain itu juga seorang tutor harus dapat mengidentifikasi kemajuan, ketercapaian, kesalahan dan kesimpulan dari proses belajar seorang murid. (Arikunto: 2012)

\section{METODE PELAKSANAAN}

\subsection{Kerangka Pemecahan Masalah}

Hal mendasar kerangka pemecahan masalah yang ditawarkan melalui kegiatan penyuluhan dan pelatihan kepada Tutor Bimbel dan Privat Matrik. Untuk lebih jelasnya dapat dilihat dalam skema di bawah ini:

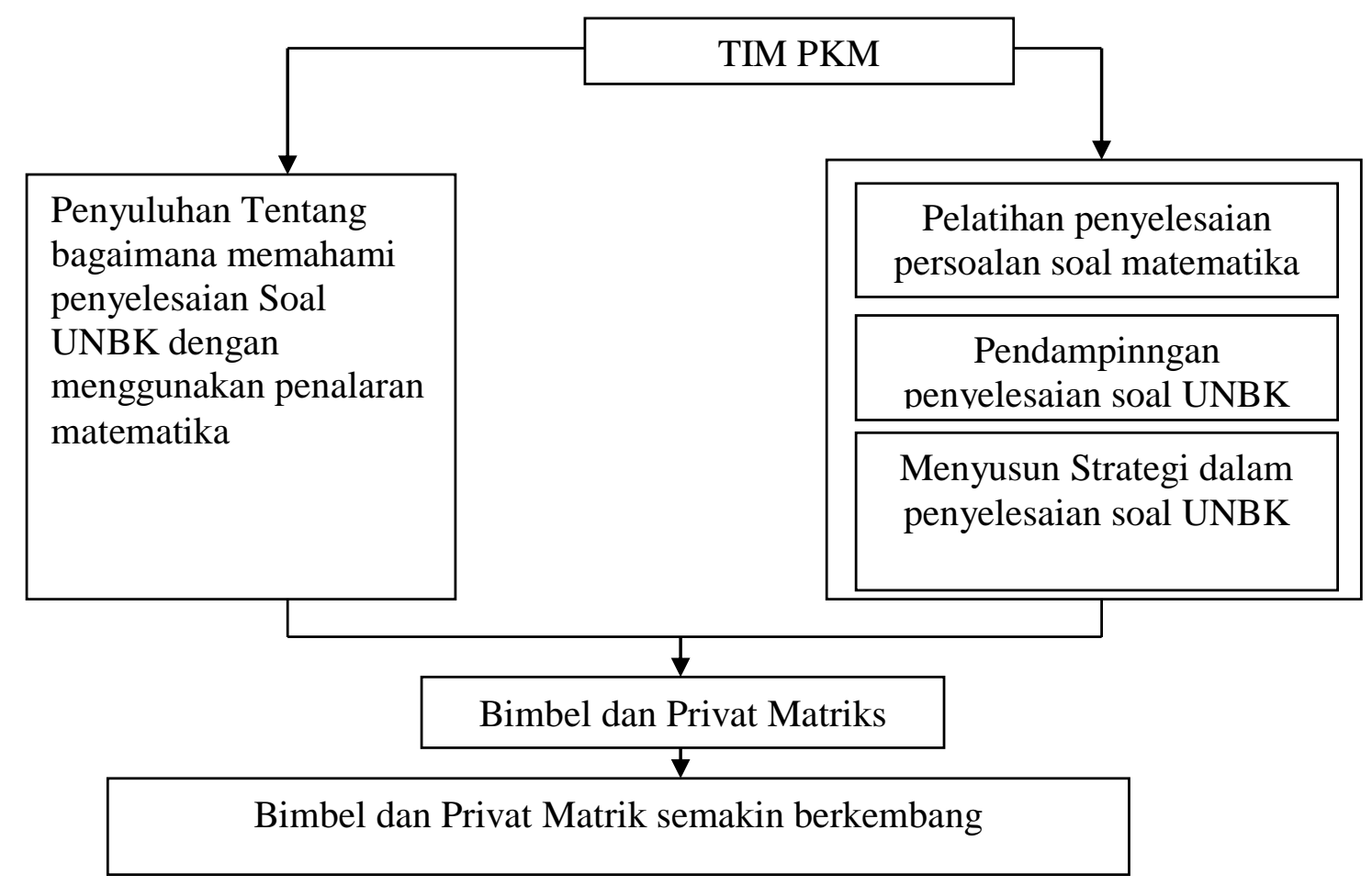

Gambar 1 Skema Kerangka Permasalahan

\subsection{Realisasi Pemecahan Masalah} yaitu:

Realisasi pemecahan masalah PKM yang dilaksanakan melalui tiga tahapan

1). Tahapan pertama yaitu tahapan penyelesaian persoalan matematika UNBK oleh tutor tingkatan SMP. Menilai hasil pekerjaan dari peserta Pkm dengan dijadikan nilai awal sebelum tritment atau $\mathrm{X}_{1}$. 
2). Tahapan kedua yaitu pembahasan soal-soal matematika dengan metode penalaran diberikan oleh Pendamping yang diberikan oleh Dosen Universitas Pamulang.

3). Tahapan ketiga yaitu mengerjakan kembali soal-soal yang sesuai dengan soal awal untuk dijadikan nilai sesudah diberikan tritment yaitu $X_{2}$. Kemudian dilanjutkan untuk membuat analisa untuk melihat apakah pengabdian kepada masyarakat yang telah dilaksanakan sesuai dengan apa yang direncanakan atau tidak.

\subsection{Khalayak Sasaran}

Sasaran program pengabdian masyarakat yang akan di tuju adalah Bimbel dan Privat Matrik yang beralamatkan di Jl. Surya Kencana Pamulang Tangerang Selatan (Depan Sekolah Muhammadiyah Pamulang) 021 - 27599008 Instagram : @ bimbelmatrikspamulang, Pamulang Timur, Tangerang Selatan. Banten. Jumlah peserta yaitu 10 Tutor.

\subsection{Tempat dan Waktu}

Tempat pelaksanaan PKm di kelas Bimbel dan Privat Matrik. Alamat Jl. Surya Kencana Pamulang Tangerang Selatan (Depan Sekolah Muhammadiyah Pamulang) 021 - 27599008 Instagram : @ bimbelmatrikspamulang. Waktu pelaksanaan pada tanggal 28, 29 dan 30 Desember 2019 dan rancangan pengabdian sebagai berikut.

Tabel 1 Rencana Kegiatan

\begin{tabular}{|c|l|c|c|c|}
\hline \multirow{2}{*}{ NO } & \multicolumn{1}{|c|}{ Kegiatan } & \multicolumn{2}{|c|}{ Waktu } \\
\cline { 4 - 5 } & & I & II & III \\
\hline 1 & Perijinan & & & \\
\hline 2 & Observasi Awal & & \\
\hline 3 & Pelatihan Anggota Tim & & \\
\hline 4 & Sosialisasi Program & & \\
\hline 5 & $\begin{array}{l}\text { Pelaksanaan penyuluhan dan } \\
\text { pelatihan bagi YCIMI }\end{array}$ & & \\
\hline 6 & $\begin{array}{l}\text { Evaluasi Pelatihan bagi } \\
\text { Bimbel dan Privat Matriks }\end{array}$ & & \\
\hline 7 & Pengolahan Data & & \\
\hline 8 & Analisis Data & & \\
\hline 9 & $\begin{array}{l}\text { Perumusan Hasil \& } \\
\text { Kesimpulan }\end{array}$ & & \\
\hline 10 & Evaluasi Program & & \\
\hline 11 & Publikasi & & \\
\hline 12 & Pelaporan & & \\
\hline
\end{tabular}


Pelatihan Penalaran Matematika Jenis Soal Ujian Nasional Berbasis Komputer (UNBK) Jenjang SMP Untuk Meningkatkan Kualitas Pengajar Dan Minat Siswa Pada Bimbingan Belajar dan Privat Matriks ...(Aden)

\subsection{Metode Kegiatan}

Pada metode pelaksanaan berikut mengacu pada faktor yang menjadi penekanan pada Pengabdian Kepada Masyarakat (PKM) kali ini. Dari banyak faktor yang disampaikan di atas, pengaju Pengabdian Kepada Masyarakat (PKM) hanya akan fokus pada metode pelaksanaan pelatihan sumber daya pengajar dalam hal peningkatan kualitas pembelajaran. Sedang untuk faktor-faktor lain akan dilakukan pembahasan lebih mendetail lagi pada pelaksanaan Pengabdian Kepada Masyarakat (PKM) di lain waktu jika memang proses pelatihan pengajar berjalan sukses dan bermanfaat bagi Bimbingan Belajar dan Privat Matriks.

Untuk mencapai target solusi dari permasalahan di Bimbingan Belajar dan Privat Matriks maka dilakukan pelaksaan pelatihan dengan langkah-langkah teknis pelatihannya sebagai berikut:

1). Pertama peserta pelatihan diberikan paket soal latihan yang bersumber dari soal Ujian Nasional atau Ujian Nasional Berbasis Komputer (UNBK) dari tahuntahun sebelumnya.

2). Peserta pelatihan mengerjakan terlebih dahulu soal tersebut dengan cara pengerjaan yang dimiliki oleh masing-masing peserta pelatihan.

3). Pemateri memperkenalkan beberapa teknis ice breaking kepada peserta pelatihan untuk mencairkan suasana pelatihan agar tercapai kondisi yang rileks sebelum proses pembahasan di tahap berikutnya.

4). Setelah peserta pelatihan selesai mengerjakan tahap selanjutnya adalah pemateri membahas paket soal latihan tersebut dengan metode penyelesaian biasa dan metode penyelesaian lain yang lebih cepat dengan basic penalaran.

5). Pemateri akan memberikan waktu untuk berdiskusi dengan para peserta pelatihan untuk membuka gagasan baru yang mungkin saja muncul pada saat pelatihan.

6). Pemateri akan memberikan beberapa soal latihan yang biasa digunakan untuk marketing ke sekolahan untuk selanjutnya dapat digunakan sebagai salah satu bahan marketing bimbingan belajar.

7). Setelah beberapa metode pengajaran disampaikan, pemateri selanjutnya menyampaikan teknik marketing dengan menggunakan soal latihan tersebut dalam bentuk penyampaian marketing.

8). Pelatihan didokumentasikan dalam video dan berkas pelatihan tapi hanya untuk dipublikasikan secara internal terbatas di Bimbingan Belajar dan Privat Matriks yang akan didistribusikan ke masing-masing cabang. 
9). Pemateri membentuk Focus Group Discusion (FGD) mengenai pengembangan yang selanjutnya diserahkan kepada manajemen Bimbingan Belajar dan Privat Matriks sebagai admin.

10). Focus Group Discusion (FGD) via whatapps selanjutnya akan mengupgrade hal yang baru dalam metode pengajaran sebelum dieksplore saat pelatihan berikutnya.

11). Segala update terbaru dapat dilakukan dokumentasi oleh pihak Bimbingan Belajar dan Privat Matriks sebagai standar pengajaran oleh pengajarnya dengan tetap diadakan evaluasi secara berkala.

12). Bimbingan Belajar dan Privat Matriks melaporkan hasil evaluasi pencapaian kualitas pengajar sebelum dan sesudah pelatihan sebagai bahan evaluasi lebih lanjut.

Pada pelaksanaannya diharapkan partisipasi dari Bimbingan Belajar dan Privat Matriks sebagai mitra untuk menghadirkan peserta pelatihan dari pengajarnya khususnya untuk mata pelajaran matematika. Sehingga proses uprade pengajar dapat bersifat menyeluruh ke masing-masing cabang. Untuk teknis pemberangkatan peserta ke acara pelatihan diserahkan kepada masing-masing cabang Bimbingan Belajar dan Privat Matriks dilanjutkan pengkondisian peserta pelatihan diserahkan kepada tuan rumah atau panitia yang ditunjuk oleh Bimbingan Belajar dan Privat Matriks. Sedang untuk teknis selama pelaksanaan sesi pelatihan nanti akan dilakukan oleh tim pengaju Pengabdian Kepada masyarakat (PKM) dibantu panitia dari Bimbingan Belajar dan Privat Matriks sebagai tuan rumah acara. Tim manajemen Bimbingan Belajar dan Privat Matriks pada pelaksanaan ikut membantu proses pelatihan dan mendokumentasikannya. Tapi proses pendokumentasian diharapkan bersifat internal dan tidak dipublish secara umum karena akan menjadi bahan untuk marketing Bimbingan Belajar dan Privat Matriks selanjutnya akan dijadikan sebagai bahan unggulan dalam layanan siswa/i Bimbingan Belajar dan Privat Matriks.

\section{HASIL DAN PEMBAHASAN}

\subsection{Hasil}

Data hasil penilaian tahap awal sebagai nilai awal yaitu menyelesaikan soal pada hari pertama PKM dijadikan X1 dan nilai akhir yang diperoleh pada hari ketiga setelah dilaksnakan penyuluhan dengan metode penalaran dijadikan data X2. Data tersebut sebagai berikut. 
Pelatihan Penalaran Matematika Jenis Soal Ujian Nasional Berbasis Komputer (UNBK) Jenjang SMP Untuk Meningkatkan Kualitas Pengajar Dan Minat Siswa Pada Bimbingan Belajar dan Privat Matriks ...(Aden)

Tabel 2 Data Hasil Penelitian

\begin{tabular}{|c|c|c|}
\hline $\begin{array}{c}\text { No } \\
\text { Peserta }\end{array}$ & Nilai Awal $\left(\mathbf{X}_{\mathbf{1}}\right)$ & Nilai Akhir $\left(\mathbf{X}_{2}\right)$ \\
\hline 1 & 75 & 80 \\
\hline 2 & 70 & 85 \\
\hline 3 & 80 & 79 \\
\hline 4 & 85 & 88 \\
\hline 5 & 82 & 80 \\
\hline 6 & 78 & 85 \\
\hline 7 & 79 & 80 \\
\hline 8 & 83 & 80 \\
\hline 9 & 80 & 86 \\
\hline 10 & 74 & 85 \\
\hline
\end{tabular}

Data hasil SPSS sebagai berikut:

Tabel 3 Paired Samples Statistics

Paired Samples Statistics

\begin{tabular}{|rr|r|r|r|r|}
\hline & Mean & N & Std. Deviation & \multicolumn{1}{c|}{$\begin{array}{c}\text { Std. Error } \\
\text { Mean }\end{array}$} \\
\hline Pair 1 & Nilai Sebelum & 78.60 & 10 & 4.526 & 1.431 \\
& Nilai Sesudah & 82.80 & 10 & 3.293 & 1.041 \\
\hline
\end{tabular}

Tabel 4 Paired Samples Test

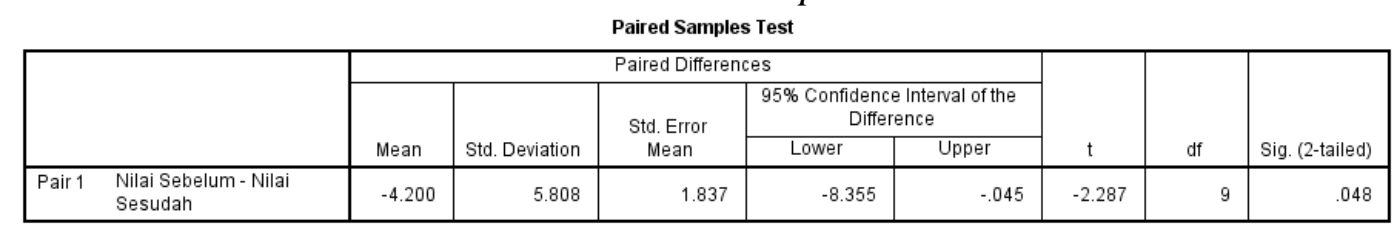

\subsection{Pembahasan}

Dari hasil perhitungan diperoleh nilai p value 0,048 lebih kecil dari pada 0,05 sehingga bisa disimpulkan bahwa penyuluhan tentang pengerjaan soal matematika UNBK dengan metode penalaran berhasil meningkatkan hasil yang lebih baik untuk tutor.

Hal-hal yang perlu ditingkatkan oleh tutor Bimbel dan Privat Matriks yaitu:

1). Meningkatkan intensitas latihan untuk meningkatkan penalaran dalam menyelesaikan soal matematika dalam UNBK

2). Memiliki soal-soal yang lebih variatif. 


\section{SIMPULAN}

Proses pengabdian kepada masyarakat yang kami lakukan dapat disimpulkan antara lain yaitu:

1). Terjadi peningkatan kemampuan penyelesaian soal matematika sesudah diberikan tritment penyuluhan penyelesaian soal dengan menggunakan metode penalaran.

2). Hal yang perlu ditingkatkan sebagai dorongan kesadaran yaitu luangkan waktu secara terus menerus untuk berlatih soal-soal yang bervariatif.

\section{DAFTAR PUSTAKA}

Anton, H. (2010). Dasar-dasar Aljabar Matriks. Jakarta: Erlangga.

Arikunto, S. (2012). Dasar-dasar evaluasi Pendidikan. Bumi Aksara 